\title{
Value Chain Analysis of Extra Virgin Olive Oil in March
}

\author{
Sule Azak and Y. Tevfik Tuzun \\ Food Engineering Department, Ege University, Izmir 35040, Turkey
}

Received: August 23, 2011 / Published: January 20, 2012.

\begin{abstract}
Today the olive oil production has an important role in many countries and Turkey remains in fifth place, with an average of about 150 thousand tons of olive oil in the world production. More than $50 \%$ of the total production of Turkey’s olive oil is supplied in Agean region. Approximately thirty-five percent of the total exportation of Turkey's olive oil forms extra virgin olive oil (EVOO), which contains a maximum of $0.8 \%$ acidity. Because of its low acid content, aroma and color, EVOO is much more valuable than the other types of olive oils. Extra virgin olive oil value chain from farmers to consumers includes the cost and selling price for every linkage of this chain. The result of this analysis shows us which one of linkage is more valuable than others or which one is in need of support. The bottler companies, larger industrial producers and some retailer shops in urban areas may have value added.
\end{abstract}

Key words: Value chain, extra virgin olive oil.

\section{Introduction}

Olive oil industry consists of four main parts in Turkey and can be seen in Fig. 1: (1) small olive oil mills; are the majority of enterprises which produce olive oil for olive farmers at a small fee or olive oil mills press olives for the farmers and charge $10 \%$ to $12 \%$ of their olive oil as a extraction fee. Usually they store olive oil in order to sell at higher price in bulk to the bottler companies. Their storage capacity and also the quality of their tanks are insufficient. (2) bottler companies; buy olive oil from oil mills or local producers. They store high quantity and quality olive oil and package especially olive oil to sell with their own brand during the year or process contract manufacturing for another company. (3) olive and olive oil cooperatives; press the farmer's olives and give them back their olive oil against a small service charge. They buy partner's olive oil in bulk from market price they store and process packaging offers and different distribution channels available in the domestic market

Corresponding author: S. Azak, food engineer, MSc., research fields: food economy and marketing. E-mail: sule_azak@hotmail.com. or export with their own brands using that. (4) industrial olive oil producers and bottlers; have also olive oil mills, refineries and packing plants. They buy olives from farmers or wholesaler at a market price and produce olive oil. They process the olive oil and sell it to the restaurants, retailers, markets and supermarkets with their brand or export packed olive oil or even in bulk.

Distiribution channels of olive oil are different between rural and urban areas in Turkey. Generally, olive oil is sold, in mini markets, traditional shops, green market or from olive oil mills or olive oil producers to consumers directly in rural area. But in urban areas, it is sold in the markets, supermarkets, restaurants, through e-trade or it is exported to the other countries.

According to the crop year in 2009/2010, olive oil production was 147 thousand tons in Turkey. It is estimated up to 160 thousand tons of olive oil production in 2010/2011 crop year. So, Turkey remains the fifth country around the world [1].

The olive oil consumption of Turkey was almost 100 thousand tons in year 2009/2010. Turkey had at least olive oil consumption with an average of 1.4 kilograms annually among Mediterranean countries [2]. 


\section{EXTRA VIRGIN OLIVE OIL MARKET}

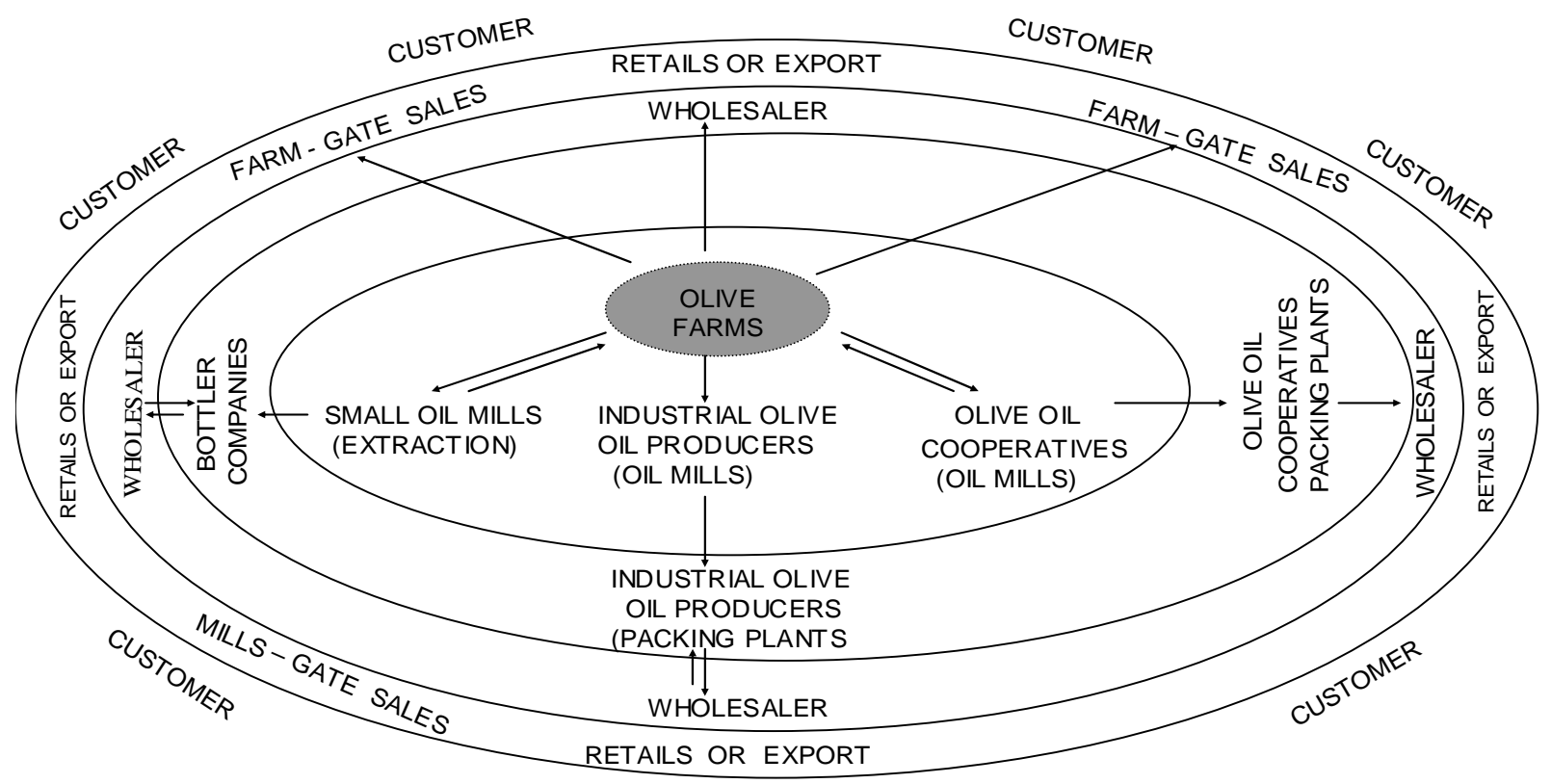

Fig. 1 Extra virgin olive oil marketing channels in Turkey.

The roughly $35 \%-40 \%$ olive oils of Anatolia classified as natural is merely pressed without any refining process, It is characterized by a greenish yellow color, most natural flavor and fruity taste. The finest of all is the extra virgin olive oil (EVOO) with a maximum acidity of $0.8 \%$ which is obtained from quality olives by cold pressing method. It is preferred when used uncooked for salad dressing or vegetable dishes. Therefore, extra virgin olive oil is much more valuable than the other types of olive oils.

In this study, the extra virgin olive oil production, market size, price and inter trade development have been analyzed by value chain analysis method to apply a new approach to the sector and business analysis providing insight through a global view of the sector and market as a whole and show which one of linkage has added value [3].

Almost $70 \%$ of the Turkish olive oil is produced in Agean Region. The olive oil production industry mostly seen at Agean Region occurs especially in Izmir which is the third biggest city of Turkey and located on the west side of Turkey. That's why, the applications of this study have been observed from Izmir and its town and willages [4].

\section{Materials and Methods}

In this study, 1 litre glass bottle of extra virgin olive oil (EVOO) in domestic market was analyzed by value chain analysis. The cost activities of extra virgin olive oils in chain configuration were shown in Fig. 2. It was determined the cost and selling price of extra virgin olive oil production from farmers to consumers in Fig. 3 and studied sample including 10 olive farms, 15 olive oil mills, 5 packing plants, 5 industrial olive oil plants and 10 distributors.

The study was based on primary data, collected through interviews with value chain operators and on secondary data, taken from national and international statics. We also used from literature and publications on this topic [5]. The material of cost and selling price was obtained from statics in 2010/2011 crop year and market price in March/2011 and cost activities were 


\section{CHAIN CONFIGURATION}

\begin{tabular}{|c|c|c|c|}
\hline VALUE CHAI & LINKS AND & OST ACTI & DISTRIBUTIC \\
\hline $\begin{array}{l}\text { OLIVE F ARMS } \\
\text { CROP PRODUCTION } \\
\text { ACTIVITIES }\end{array}$ & $\begin{array}{l}\text { OLIVE OIL MILLS } \\
\text { EXTRACTION } \\
\text { ACTIVITIES }\end{array}$ & $\begin{array}{l}\text { PACKING } \\
\text { PLANTS } \\
\text { PACKING } \\
\text { ACTIVITIES } \\
\end{array}$ & $\begin{array}{l}\text { DISTRIBUTION } \\
\text { ACTIVITIES }\end{array}$ \\
\hline $\begin{array}{l}\text {-Soil management } \\
\text {-Irrıgation } \\
\text {-Pruning } \\
\text {-Fertilisation } \\
\text {-Plant health } \\
\text { treatment } \\
\text {-Harvesting } \\
\text {-Olive transportation } \\
\text { to the mill }\end{array}$ & $\begin{array}{l}\text {-Fruit reception, } \\
\text { clasification and } \\
\text { cleaning } \\
\text {-Crushing, mixing, } \\
\text { centrifugation, } \\
\text { settling, } \\
\text {-quality control } \\
\text {-classification, } \\
\text {-Oil storage } \\
\text {-Oil transportation to } \\
\text { the packing plant }\end{array}$ & $\begin{array}{l}\text {-Oil reception } \\
\text {-Quality control } \\
\text {-Storage } \\
\text {-Filtration } \\
\text {-Packing:Filling, } \\
\text { sealing, } \\
\text { labelling, } \\
\text { packaging } \\
\text {-Storage } \\
\text {-Transportation } \\
\text { to destination }\end{array}$ & $\begin{array}{l}\text { Retail markets: } \\
\text {-Marketing research } \\
\text {-Reception and } \\
\text { storage } \\
\text {-Shelf placement and } \\
\text { Support } \\
\text {-Product care; } \\
\text { replenishment, } \\
\text { spoilage and expiry } \\
\text { control } \\
\text { Exportation: } \\
\text {-Marketing research } \\
\text {-Proforma Invoice } \\
\text {-The other documents } \\
\text {-Custom facilities } \\
\text {-Olive oil exportation }\end{array}$ \\
\hline
\end{tabular}

Fig. 2 The cost activities in extra virgin olive oil production.

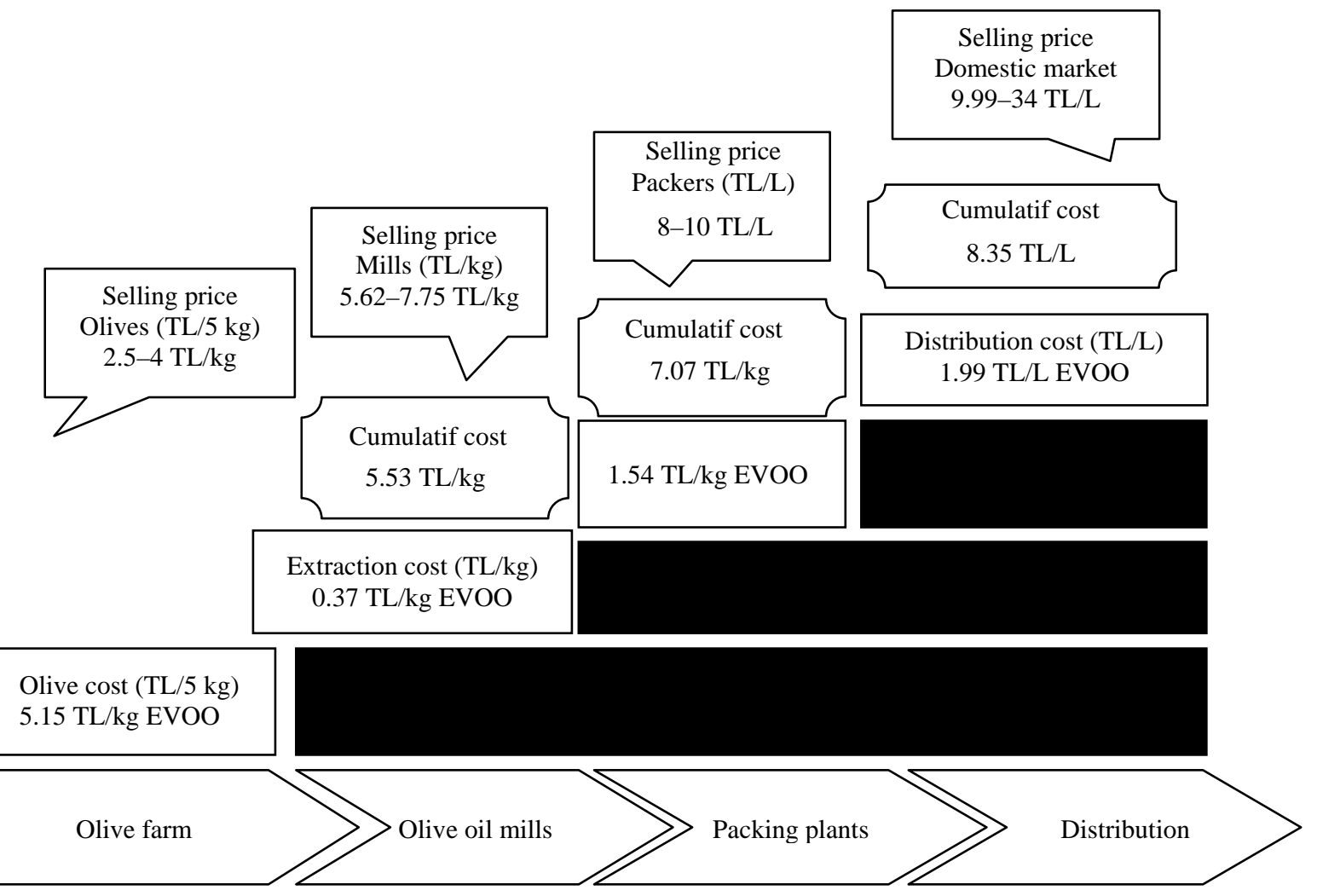

Fig. $31 \mathrm{~L}$ glass bottle of extra virgin olive oil value chain analysis in Turkey in March of 2011. 
collected from olive oil farms, oil mills, packing plants and also markets and supermarkets by face to face applying "Knowledge Attitude Practise (KAP) Method" is focused on evaluations that measure changes in human knowledge, attitude and practice [6].

\section{Results and Discussion}

According to Union of Turkish Chambers of Agriculture statics and farmer interwiews, the total production costs in farm including soil management, irrigation, pruning, fertilization, plant healt treatment, harvesting, adding interest and depreciation costs were $588.37 \mathrm{TL} / \mathrm{da}$. Average quantity of olive was 569.50 $\mathrm{kg} / \mathrm{da}$. So, the cost of olive per kilo was $1.03 \mathrm{TL} / \mathrm{kg}$ [7]. The selling price of olives was between 0.5 and 0.8 $\mathrm{TL} / \mathrm{kg}$. Please note that 5 kilograms of olive were necessary for one kilogram of olive oil. So the cost of olives was $5.15 \mathrm{TL}(1.03 \times 5)$ and the selling prices of olives were between 2 and 4 TL for one kilogram EVOO in the olive farms.

The cost activities of olive oil mills consist of fixed cost and variable costs including labor cost, electricity, water and other costs were collected through interview by KAP method. The average investment cost of small oil mills was 120,000 USD and average labor cost for person including insurance was $60 \mathrm{TL} /$ day. The other cost, i.e. electricity, water and others for one kilogram of EVOO were almost $0.20 \mathrm{TL} / \mathrm{kg}$. After calibration of the data, total weighted average cost of oil mills was found to be $0.37 \mathrm{TL} / \mathrm{kg}$. The selling price of extra virgin olive oil in bulk was between $6.0 \mathrm{TL} / \mathrm{kg}$ and 6.5 $\mathrm{TL} / \mathrm{kg}$ in oil mills depends on their stock. The price of extra virgin olive oil was between $5.62 \mathrm{TL} / \mathrm{kg}$ and 6.5 TL/kg in the cooperatives in March of 2011.

Packing plants apply reception and quality control of olive oil for organoleptic structure, filtration, filling, sealing and packing, storage olive oil and transportation to the final destination [8]. Approximately $1 \%$ of olive oil is lost after filtering. Their cost activity consists of fixed cost and variable cost including electricity, labor cost, packing material, label cost, and also filtering lost etc.. The cost activities were collected by KAP method and calculated. So the weighted average cost was found $1.54 \mathrm{TL} / \mathrm{kg}$. Also the density of the olive oil approximately $0.9 \mathrm{gr} / \mathrm{cm}^{3}$ and gives $10 \%$ advantage to the packing plants. According to Turkey Chambers and Commodity Exchanges, the price of extra virgin olive oil as bulk was $7.5 \mathrm{TL} / \mathrm{kg}$ [9], the price of cooperatives and oil mills was between $5.62 \mathrm{TL} / \mathrm{kg}$ and $6.5 \mathrm{TL} / \mathrm{kg}$. The average selling price of ex-factory for 1 litre glass bottle of EVOO changed from 8 to $10 \mathrm{TL} / \mathrm{L}$ depending on their stock, capacity and administrative costs in March of 2011.

We mentioned different distribution channel for olive oil in this study. The average selling price of extra virgin olive oil for $1 \mathrm{~L}$ glass bottle of EVOO was between 9.99-15 TL/L in markets and supermarkets. The selling price of retailer shops and some small markets in urban area was between 12 and 24 TL/L. It was noticed that the price of extra virgin olive oil was very high in some e-trading websites and private olive oil shops. Especially their price varied between 18-34 $\mathrm{TL} / \mathrm{L}$ depending on their organics or conventional extra virgin olive oils.

The average selling price of EVOO in markets and supermarkets is 11.54 without tax. Costs of the supermarkets consist of administrative cost and labor cost, reception and storage. After calibration of the data, the weighted average cost was $1.99 \mathrm{TL} / \mathrm{L}$ in the supermarkets.

\section{Conclusion and Recomendation}

The study shows that the farmers are in need of successful olive oil policies, in order for them to survive in the market. They should reduce their cost, especially, harvesting labor cost and should use modern harvesting methods to produce high quality and quantity extra virgin olive oil which is more valuable than the other types of olive oils. They have to transfer the olives to the oil mills as soon as possible without mixing the top and bottom olives. Other problems such as the lack of warehouses and the stored 
olive oil in unsuitable conditions have been noticed.

Most olives are produced without using fertilizers and chemicals. Actually, the production is organic. But they are not certified. Actually organic olive oils have a higher price than the conventional ones. In short, the government should give some technical assistance to farmers in order to increase productivity and profitability.

Although selling in bulk to the final consumers is not allowed by the gowerment, because of the high cost activities, the farmers and oil mills sell their olive oil directly to final customers. So it leads unfaired consumption in Turkey. Some oil mills are very old or uncared. They produce low quality olive oil at low capacities. Government has to increase the control of the olive mills and give them some technical and economical support to improve their uncare conditions and encourage, to sell the olive oil with their own brands. It was noticed that there was a dangerous gap between domestic and international markets. If the olive oil production increases, the margin of market prices will decrease. Also, the government should support the advertisement campaigns to increase the consumption of olive oils in Turkey.

\section{References}

[1] International Olive Council (IOOC), World Olive Oil Figures (production and exportation), (November 2010), http://www.internationalolive.oil.org.

[2] International Olive Council (IOOC), World Olive Oil Figures (comsumption), (November 2010), http://www.internationalolive.oil.org.

[3] R. Kaplinsky, Globalisation and unequalisation: What can be learned from value chain analysis?, Journal of Development Studies 37 (2) (2000 ) 117-146.

[4] Prime Ministry Republic of Turkey, Turkish Statistical Instute, Turkey's Statistical Year Book, Turkstat, 2009, http://www.turkstat.gov.tr.

[5] L. Leonetti, D. Imami, A. Stefanllari, E. Zhllima, The olive and olive oil value chain in Albania, Development Solution Associates (DSA), Tirana, May 2009, p. 4.

[6] E. Karlyn, R. Walker, Knowledge, Attitudes and Practices (KAP): Studies for Water Resources Projects, Water Resources Center, University of Minnesota, 2008, p. 2.

[7] Union of Turkish Chambers of Agriculture, The cost table of the olive oil, 2009-2010, www.tzob.org.tr/tzob_eng/tzob_home_english.htm.

[8] C. Sanchez Lain, The Value Chain and Price Formation in the Spanish Olive Oil Industry, Essaouira, June 22, 2010, p. 30.

[9] The Union of Chambers and Commodity Exchanges of Turkey, http://www.borsa.tobb.org.tr./fiyat_borsa0.php. 